\title{
Implementation of Long-Life Education in Indonesian Medical Education
}

\author{
Vina Ariesta Dewi \\ Department of Educational Management \\ Universitas Negeri Malang, Indonesia \\ vheena1@yahoo.co.id
}

\author{
Ali Imron \\ Department of Educational Administration \\ Universitas Negeri Malang, Indonesia \\ ali.imron.fip@um.ac.id
}

\author{
Achmad Supriyanto \\ Department of Educational Administration \\ Universitas Negeri Malang, Indonesia \\ a.supriyanto.fip@um.ac.id
}

\author{
Ahmad Suriansyah \\ Department of Educational Management \\ Lambung Mangkurat University, Indonesia \\ a.suriansyah@yahoo.co.id
}

\author{
Aslamiah \\ Department of Educational Management \\ Lambung Mangkurat University, Indonesia \\ aslamiah.fkip.unlam@gmail.com
}

\begin{abstract}
Education is a process of transforming knowledge, values and skills, inside and outside of school that lasts for life, from generation to generation. Education brings hope to everyone to achieve their goals and achieve a better quality of life. The importance of the meaning of education for one's life to continuously improve the quality of him self and his life, gave birth to a conception of thought about the importance of lifelong education. This is an answer from time and time that is very dynamic, where there will always be progress, new things, and challenges that must be conquered at every stage of the times. This article is made by reviewing; collecting various references both text books and reference journals that are used as references in discussing concepts. Theory and the notion of lifelong education or Long-Life Learning (LLL) in its relevance and its implementation in medical education long life education is the solution to deal with it. One concrete example of the implementation of lifelong education can be seen clearly in medical education, where lifelong education in medicine is known as Continuing Medical Education (CPD) which is implemented with the aim to ensure the quality and quality of doctors and the health services they provide to the community during their medical practice, throughout their lives. This article is made by reviewing; collecting various references both text books and reference journals that are used as references in discussing concepts. theory, and the notion of lifelong education or Long-Life Learning (LLL) in its relevance and its implementation in medical educationEducation in the medical world is fully aware of the importance of implementing lifelong education to continue to be lived in accordance with the times and the times. The form of lifelong education, whether carried out in formal or informal education, continues continuously throughout life, is a condition that must be met within a certain period of time, to ensure the legality and quality of the medical practice it carries out. Medical education is the real implementation of long-life education.
\end{abstract}

Keywords: long life education; life long learning; continuing medical education

\section{INTRODUCTION}

Education is basically a process of communication which contains a transformation of knowledge, values and skills, inside and outside of school that lasts for life, from generation to generation (Siswoyo, 2008). Departing from this, Lifelong Education, or what we know as Long Life Learning (LLL) is a conception from thinking process which is born along with the progress of the times and demands for competencies that are continually improved by each individual. This of course should be we understand comprehensively, to then be able to implement in our lives, especially among the intelligentsia (Collins, 2009).

An education system that has an educational paradigm implemented from someone from birth to death is called Long Life Education (LLE). Malcolm Shepherd, known as the Father of Life-long Education, stated that LLL would be the principle that governs all lines of education. The term education throughout life today is very familiar in the discussion of the world of education (Duyff, 1999).

Life-long education is a familiar phenomenon because of expectations through lifelong education; humans continue to and always learn through events that occur in everyday life or experiences that have been experienced. The concept of education throughout life does not recognize the age limit, all human beings who are still young to old age can still be students, because lifelong ways of learning can be done anywhere, anytime, and by anyone (Abukari, 2005).

One of the concrete forms of implementation of education throughout life is that it can be found in the world of medical education. The medical education system in Indonesia has a very strategic role in producing qualified doctors. Starting from the thought, which qualified doctors, will provide quality health services to the community.

As the which one strategies to reach that goals, that is the policy to continuously improve the competencies of a doctor to as the part of Self Quality Improvement, namely with the existence of LLE / LLL or today, especially in medical medicine, life-long education is known as Continuing Medical Education (CME)), in Indonesia this is known as the Continuous Professional Education Development Program (CPD) / (P2KB) (KKI, 2012). 
Medical education is a learning process that educates and creates doctors who have professional skills, knowledge and behavior. In accordance with the vision and mission of medicine and the emergence of a new paradigm namely Evidence-based medicine, patientoriented medicine and the view of medicine in carrying out their duties expected to be able to apply a doctor based on a scientific, by reducing the role of intuition (Rahman, 2011).

With the demands of high needs and expectations by the community for qualified doctors, for this reason, Life-long Education for doctors, or Continuing Medical Education to continue to improve their knowledge, and their ability to carry out noble duties, is a necessity and necessity. for doctors to be able to provide assistance and the best and prime services in the world of health for the people of Indonesia (DPR RI, 2011).

\section{METHOD}

This article is made by reviewing; collecting various references both text books and reference journals that are used as references in discussing concepts. Theory and the notion of lifelong education or Life Long Learning (LLL) in its relevance and its implementation in medical education, which adopted the concept of Life Long Education in a journey known as the Continuing Medical Education (CME) or Sustainable Medical Education. Furthermore, after going through a series of literature studies, and thought processes, then all the theories, concepts, facts and information obtained in connection with the concept of Lifelong Education and Medical Education in Indonesia, are comprehensively integrated into a single entity that is expected to be a contemplation and inspiration for us together.

\section{RESULTS}

The concept of thinking "Life Long Learning" itself has been indirectly raised by one of the famous scientists, namely John Dewey, he revealed that: "Educational processes have no end beyond it self in its own and end" (Collins, 2009). The context in this case that we can understand is that the educational process and the need for education last for a lifetime. It's never too late, or tired of studying.

There are several rational reasons that arise for the concept of Life-long Education, among others proposed by Paul Lengrand, in his book entitled "Introduction to Life Long Education, Paul argues that there are many challenges in various forms and variations that spread both in countries and countries. Developing requires education to be formulated into lifelong education or lifelong education. As for the challenges referred to in this case, including: innovation of science, and technology, the pace of change, demographic expansion, information and crises that occur in life patterns, and political challenges (Courtney, 1989).

LLE or LLL means combination of processes in which people build the entire experience of the situation and turn it into complete collaboration between Intelegensia Quotient (IQ), Emotional Quotient (EQ), Addversity Quotient (AQ), and Spiritual Quotient (SQ), as results in th ir own biography. Learning in the field of medical education is not only about we have to know, but we also need to do, in another word besides we need to know the theory, we have to practice the theory, evaluate, and apply the information (Lee, 2006). If we want to be successful by lifelong learning concept, so it means we need to know about the learning strategies, how to use the knowledge into daily life, and also we must have the endurance in the educational process (Foster, 1988).

Life-long education must be based on the principles of education, including: education will only end if humans have died and lifelong education is a strong motivation for students to plan and conduct organized and systematic learning activities (Sudjana, 2001). The application of lifelong learning in realizing the learning community greatly contributes to improving the value of people in society. With this improvement, the dignity in the community can be lifted in the eyes of the world (Gaymer, 2006)

Associated with some of the above understandings regarding the application of lifelong education, we associate it with medical education which is very clear in applying this to every prospective doctor, and doctors. Medical education directs every prospective doctor and doctors, to continue to develop their knowledge, before becoming a doctor, even after becoming a doctor. A concrete example that can be understood from this, that even a doctor after undergoing a long education (6-7 years / the fastest standard) to get a profession as a doctor, and after becoming a doctor he is still faced with demands and obligations to fulfill The target is known as the Continuing Professional Education Development Program (CPD) or known as Continuing Medical Education (CME) as a requirement to extend the Doctor's Registration Certificate (STR) which must be extended and renewed every 5 years, which is one of the basic legalities for doctors to continue to undergo medical practice in the community (Konsil Indonesian Medicine, 2012). Schematically, the level of medical education in Indonesia can be summarized in the following scheme (Figure 1).

This continues until the end of life, without a pension limit, given that the medical profession is a lifelong profession that has no retirement limit, as long as the doctor is competent in carrying out his medical practice, so throughout life, doctors must continue to learn, improve their knowledge, expertise, competencies along with the times, on this basis it may be said that medical education is the real lifelong education process.

In reality, the concept of $L L E$ / LLL has a noble purpose and purpose in improving the quality of each individual, because the concept Life Long Education continues to accelerate ourselves in increasing knowledge, honing skills, improving skills, which in fact must always improve and progress from what we have before, in accordance with the times and new things around us (Duyff, 1989).

The old saying "Demand Science to China" is certainly not just a wise sentence without meaning, the saying gives a strong motivation for every individual to be tired of studying, and improve their quality. This point is also the basis of lifelong education in the world of medicine, so that every doctor should be very understanding of the essence and tendency of Continuing Medical Education (CME) as a form of responsibility and 
consequences that must be followed towards life commitments he chooses to undergo a doctor's profession. Every doctor is encouraged to constantly improve his knowledge through a series of activities to develop his knowledge and competence as a doctor. There is never a word of tiredness in studying (Nancy, 2008).

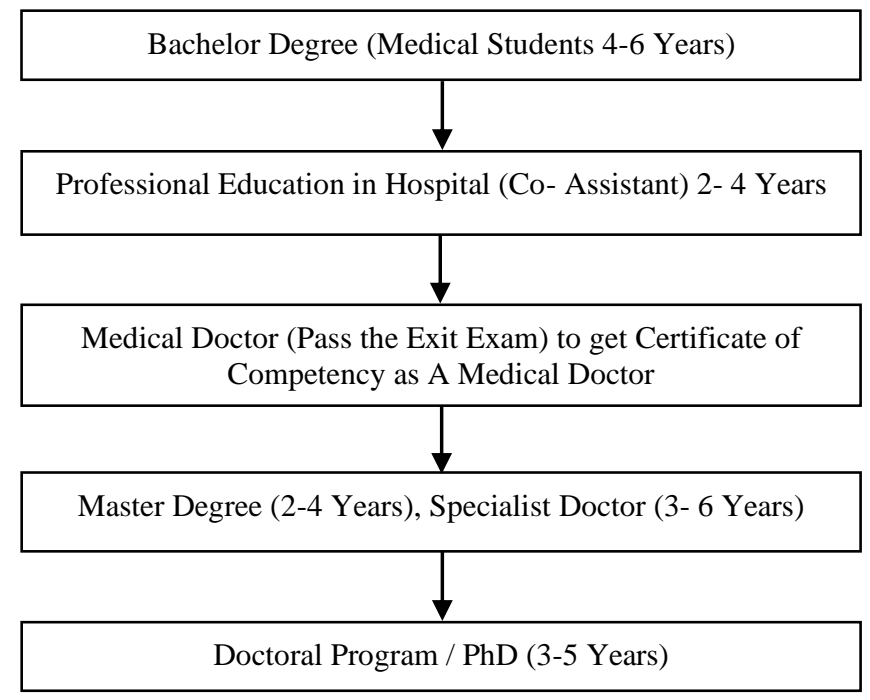

Figure 1

The Level of Medical Education

\section{DISCUSSION}

Medical Education and Life-long Education are two things that are inseparable. This is clearly evident from the goals referred to in the concept of lifelong education, namely: to continuously improve the knowledge, quality and ability of individuals in accordance with the challenges and development of the times, so that each individual can be better and better from time to time, to achieve its optimal standard of living (Lestari, 2012). This is certainly very relevant to education in the world of medicine which is indeed required to constantly improve its knowledge and abilities as a doctor, through a series of learning processes both formal and informal education (Loedin, 2005).

In order to provide excellent health services to the community, the government in this case through the Ministry of Health seeks to improve the performance and quality of public health efforts and individual health efforts (KKI, 2012) and this can certainly be achieved if it is matched by an increase in the quality and quality of doctors who provide health services themselves.

The Indonesian Doctors Association (IDI) as a medical profession organization is one of stakeholders the health servicewho are also responsible for ensuring the implementation of quality medical services. IDI has issued Guidelines for the Implementation of Sustainable Professional Education Development Program (P2KB) / (Continuing Professional Development) / (Continuing
Medical Education) for all its members as an application form of the Law of the Republic of Indonesia Number 29 of 2004 concerning Medical Practices article 28 paragraph 1 , which states that every practicing doctor or dentist is required to attend continuous medical or dentistry education and training organized by professional organizations (IDI) and other institutions accredited by pofesi organizations (IDI) in order to absorb the development of medical or dental science and technology (PB IDI, 2007).

The Continuing Professional Education Development Program (P2KB) is a concrete fact of Life Long Learning in order to increase the quality of doctors, given that a doctor plays an important role in improving the quality of medical practice services, while making doctors more professional in accordance with dignity and the honor of his profession in order to fulfill humanity's expectations, people's expectations, and the hopes of the nation. (PB IDI, 2007).

Descriptively, it can be said that the process of education in the world of medicine is indeed not easy, and inevitably someone who has committed to be a doctor must accept the consequences of undergoing lifelong educational commitment, as long as he is still undergoing medical practice. The following Table 1 of aspects of the CPD aspects that must be met by doctors, namely as follows (PB IDI, 2007).

Table 1

Proportions of Professional Activities that Ideally Should be Achieved by Physicians

\begin{tabular}{|c|l|c|c|}
\hline $\begin{array}{c}\text { No Area } \\
\text { of }\end{array}$ & \multicolumn{1}{|c|}{ Activity } & $\begin{array}{c}\text { Portion of Expected } \\
\text { Achievements }\end{array}$ & $\begin{array}{c}\text { Maximum Value of SKP per 5 } \\
\text { Years }\end{array}$ \\
\hline 1. & Learning Area & $40-50 \%$ & $100-125$ \\
\hline 2. & Professional Sphere & $40-50 \%$ & $100-125$ \\
\hline 3. & Community Service Area & $5-15 \%$ & from 12.5 to 37.5 \\
\hline 4. & Scientific Publications Sphere & $0-5 \%$ & 0 to 12.5 \\
\hline 5. & Sphere Development of Science & $0-5 \%$ & $0--12,5$ \\
\hline
\end{tabular}


Addition to taking formal education (undergraduate medical education, doctor profession education, spresialist doctor education, consultant doctor education, postgraduate, and doctoral program), a doctor must still be required to undergo a Continuing Professional Education Development Program (P2KB), through seminars, workshops, writing scientific papers, community service and so forth which becomes an assessment standard that must be achieved by a doctor in gathering a number of Professional Credit Units (SKP) that have been adjusted according to the level of education Extend the Certificate of Registration (STR) of the Doctor so that he can continue to carry out his medical practices in the community (Konsil, Indonesian Medicine, 2012). The following is a picture of the Credit Unit Profession scheme needed to extend STR (Figure 2).

Based on the Continuing Professional Education Development Program, we can understand that lifelong education in the world of medicine is an effort to ensure the quality and quality of doctors in their daily practice and It is also a form of systemic guidance to improve and develop knowledge, skills and attitudes of doctors so that they can always run their profession properly. The Continuing Professional Education Development Program is also an integral part of the practice permit mechanism (PB IDI, 2007).
The Continuing Professional Education Development Program is tailored to the needs of each doctor and is carried out continuously. The learning material contains elements of integrated practice and theory because the ultimate goal is to improve medical services. Therefore, this program should be implemented in an integrated manner and become part of medical services (PB IDI, 2007).

Professional Education Development Program Sustainability is an independent learning activity which is self directed and practice based, so the main element is recording for the purpose of monitoring by the association. In this case the use of information technology will be very helpful, therefore it is highly recommended that all associations build arecording system web based even though manual recording is still possible. This internet system in the future will be connected to the system at the IDI level (PB IDI, 2007).

Every doctor or dentist who practices is obliged to be entitled to the opportunity to undergo a Continuing Professional Education Development Program carried out by the collection of doctors in accordance with the characteristics of his practice. This program is an integral part of the certification process. For that he is obliged to register his participation in the association concerned (PB IDI, 2007).
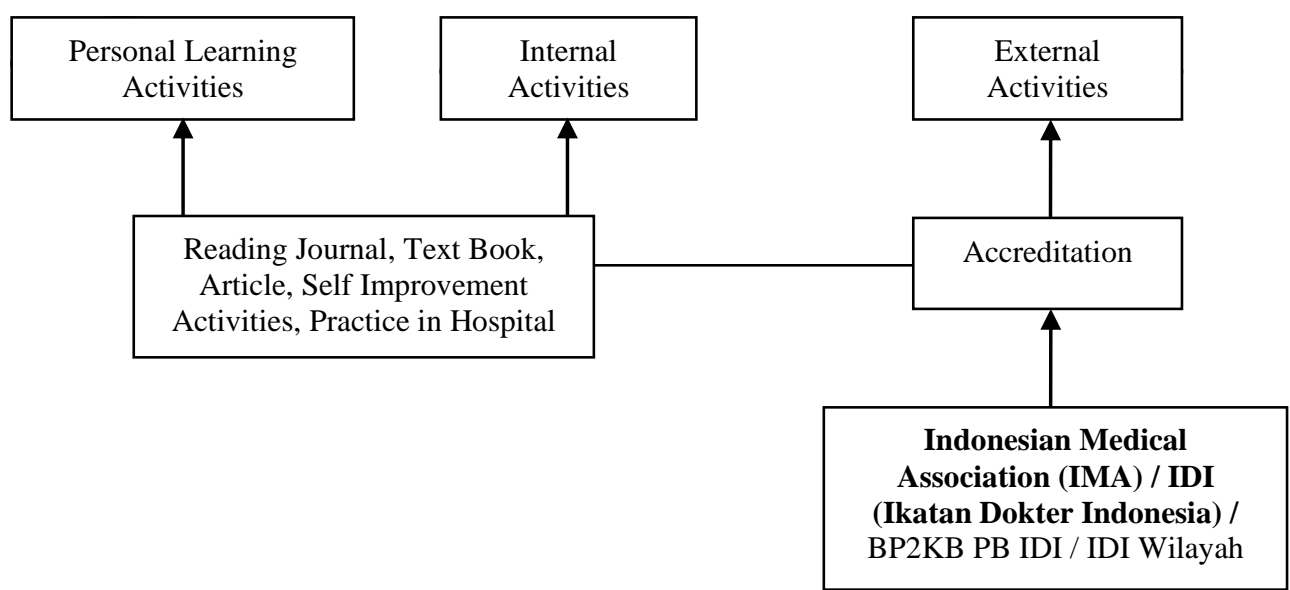

Figure 2

Schema Credit Units Profession

Table 2

Target Number Achievement SKP Doctors 250 SKP in 5 Years

\begin{tabular}{|l|l|l|}
\hline \multicolumn{1}{|c|}{ Sphere } & \multicolumn{1}{c|}{ Activities } & \multicolumn{1}{c|}{ Note } \\
\hline I & Performance Learning & Minimum 50 / maximum 75 \\
\hline II & Performance Professionals & Minimum 75 / maximum 150 \\
\hline III-performance & Community Service / Professional & Minimum 25 / Maximum 50 \\
\hline IV & Scientific Publication Performance & Minimum 0 / Maximum 100 \\
\hline V & Science Development Performance & Minimum0 / Maximum 100 \\
\hline
\end{tabular}

\section{CONCLUSION}

Life-long education means the process for people to increase their quality (knowledge, value and skillis) as the strategies to face every challenge in globalization era, which influences each other currently in disruption era. We need to imporove our value, competency and our quality continuously, and it's called Life Long Learning.Lifelong education is the answer to the challenges of the times for every individual. This everchanging world requires a flexible system. Education must continue to move and recognize innovation
continuously.Life Long Learning is a familiar phenomenon because of expectations through life-long learning; humans continue to and always learn to improve their knowledge, abilities and expertise.

One of the concrete forms of implementation of education throughout life is that it can be found in the world of medical education. The medical education system in Indonesia has a very strategic role in producing qualified doctors. One effort to continuously improve the quality and competence of a doctor, namely the existence of Life-long Education or known as Life Long Learning 
(LLL) which in the medical world is better known as Continuing Medical Education (CME) or in Indonesian is called Sustainable Professional Education Development Program (P2KB).

Medical Education and Life-long Education are two things that are inseparable, because the concept of lifelong education is an effort that must be implemented in education in the medical world to ensure the quality and quality of doctors in providing the best and best health services for the community. Lived by a doctor both formal and non-formal education must continue until the end of the verse, as long as a doctor is still undergoing medical practice. Therefore it is very appropriate that education in the world of medicine is said to be The Real Life Long Learning, The Real Life Long Education.

\section{REFERENCES}

[1] Abukari, A. 2005. Conceptualising Lifelong Learning: A reflection on lifelong learning at Middlesex University (UK) and Lund University (Sweden). European journal of education, 40 (2), 143-154.

[2] Allains, Stephanie. 2014. Quality Assurance in Education. Johannesburg: Centre for Education Policy Department.

[3] Collins, J. 2009. Lifelong Learning in the 21st Century and Beyond. Journal of Radio Graphics, 29 (2), 613-622.

[4] Courtney, S. 1989. Adult and Continuing Education. In SB Merriam \& PM Cunningham (Eds.), Handbook of Adult and Continuing Education, San Francisco, USA: JosseyBass publishing.

[5] DPR RI. 2011. Academic Text on Medical Education. Jakarta: DPR.

[6] Executive Board of the Indonesian Doctors Association (PB IDI). 2007. Development of Sustainable Professional Education. Jakarta: PB IDI.

[7] Duyff, R. L. 1999. The Value of Lifelong Learning: Key Element in Professional Career Development. Journal of Am Diet Assoc, 99 (5), 538-543.
[8] Foster, SE. 1988. Professionalization of the Adult Literacy Workforce: Background Paper Prepared for Project on Adult Literacy. Southport Institute for Policy Analysis, Connecticut, USA: ERIC.

[9] Gaymer, D. M. 2006. Continuing Education and Lifelong Learning Trends. In Helms, M. M., (Ed.) Encyclopedia of Management (p. 128-131). Farmington Hills, Michigan, USA: Thomson Gale Publishing.

[10] Indonesian Medical Council. 2012. Doctor of Professional Education Standards. Jakarta: KKI.

[11] Laal, M., Laal, A., \& Aliramaei, A. 2014. Continuing Education; Lifelong Learning. Journal of Elsevier Procedia Social and Behavioral Sciences, 116(8), 40524056.

[12] Lestari, Puji. 2012. Medical Education Policy in Indonesia. Journal of Short Information on Social Welfare, 4(8), 9-12.

[13] Loedin, A. A. 2005. History of Medicine on Earth Indonesia. Jakarta: PT Main Library Graffiti.

[14] Myers, J. L., Greenson, M. D., \& Joel, K. M. D. 2017. Life Long Learning and Self Assessment. Journal of Pro Quest, 12(18), 851-853.

[15] Nikulina, N. 2014. Cognitive Management Theory and Practice in the Organization. Procedia Social and Behavioral Sciences Elsevier Journal, 166 (8), 441-445.

[16] Rahman, Kl. 2011. Curriculum for Medical Education. Bali: Faculty of Medicine, Udayana University.

[17] Saadat, V., \& Saadat, Z. 2016. Organizational Learning as a Key Role of Organizational Success. Elsevier Procedia Social and Behavioral Sciences Journal, 230(1), 219-225.

[18] Sallis, E. 2011. Total Quality Management in Education. Jogjakarta: IRCSoD.

[19] Sonhadji, A. 2018. Manusia, Teknologi dan Pendidikan. Malang: Universitas Negeri Malang.

[20] Tim Pengembang SPMI (Direktorat Penjaminan Mutu Ristekdikti). 2018. Pedoman Sistem Penjaminan Mutu Internal. Jakarta: Ristekdikti.

[21] Yusuf, A. 2012. Long Life Education Unlimited Learning. Pedagogia Journal, 1(2), 111-129. 